\title{
Kongenital trombotisk trombocytopenisk purpura
}

\begin{abstract}
BAKGRUNN Kongenital trombotisk tromboctyopenisk purpura er en sjelden, arvelig sykdom. Klinisk presenterer den seg med anfallsvis opptredende mikroangiopatisk hemolytisk anemi og trombocytopeni med varierende grad av skade på indre organer. Tilstanden kan debutere i nyfødtperioden, men kan også presentere seg første gang i voksen alder. Her $i$ landet er det en spesielt høy forekomst av kongenital trombotisk tromboctyopenisk purpura, så det er særlig viktig at norske leger kjenner til tilstanden. I denne artikkelen gjennomgår vi hovedtrekkene ved sykdommen, inkludert diagnostikk og behandling, og presenterer fremtidige behandlingsmuligheter.
\end{abstract}

KUNNSKAPSGRUNNLAG Artikkelen er basert på litteratursøk i PubMed samt forfatternes egen forskning og kliniske erfaring.

RESULTATER Vi fant stor variasjon i alvorlighetsgrad ved kongenital trombotisk tromboctyopenisk purpura: fra dødsfall i nyfødtperioden til sykdomsfrie intervaller på flere år. En utløsende faktor er oftest nødvendig før et anfall. Akutte anfall behandles med plasmainfusjoner. Omtrent halvparten av pasientene har hyppige anfall og trenger forebyggende infusjoner for å unngå organskade. Risikoen for anfall er størst i nyfødtperioden, under graviditet og i forbindelse med infeksjoner.

FORTOLKNING Forskningsbasert kunnskap om langtidsutsiktene ved kongenital trombotisk tromboctyopenisk purpura mangler. Retningslinjer for hvem som trenger forebyggende behandling er ønskelig. Et internasjonalt pasientregister vil kunne gi nyttig kunnskap og danne basis for bedre retningslinjer i oppfølging og behandling av disse pasientene.

Kongenital trombotisk trombocytopenisk purpura ble første gang beskrevet av Irving Schulman i 1960 hos en ung jente med hemolytisk anemi, residiverende trombocytopeni og blødningstendens (1). Jefferson D. Upshaw beskrev senere et lignende tilfelle og foreslo mangel på en ukjent plasmafaktor som årsak til sykdomsbildet, ettersom både hans og Schulmans pasient fikk korrigert trombocytopenien etter tilførsel av plasmaholdige blodprodukter (2). Tilstanden gikk lenge under betegnelsen UpshawSchulmans syndrom.

Senere oppdaget man at disse pasientene har ultralange, klebrige von Willebrands faktor-multimerer i plasma. Dette skyldes mutasjoner i genet for proteasen ADAMTS13 (A Disintegrin And Metalloprotease with ThromboSpondin type1 motifs-13), som spalter von Willebrands faktor $(3,4)$. Tilstanden kalles nå kongenital eller hereditær trombotisk trombocytopenisk purpura, men kan debutere i voksen alder.

Sykdommen er karakterisert ved anfallsvis opptredende mikroangiopatisk hemolytisk anemi, trombocytopeni og varierende grad av organskade. Tilstanden er arvelig og rammer både kvinner og menn. Ubehandlet innebærer anfall høy dødelighet, men ved rask diagnose og behandling overlever de fleste (5). Prognosen på lang sikt vet vi foreløpig ikke nok om.

Kongenital trombotisk trombocytopenisk purpura er tidligere omtalt i Tidsskriftet $\mathrm{i}$ spalten Noe å lære av (6). Her gir vi en over- sikt over sykdommen med vekt på diagnostikk og behandling og på den spesielle situasjonen vi har her i landet - med en uvanlig høy forekomst.

\section{Kunnskapsgrunnlag}

Artikkelen er basert på litteratursøk og gjennomgang av litteraturlister fra relevante artikler. Vi benyttet PubMed-databasen og utførte fire ulike søk med søkeordene «thrombotic thrombocytopenic purpura», «Upshaw Schulman syndrome», «congenital» og «familial» (fig 1). Litteratursøket ble avsluttet 15.3.2015. Artiklenes relevans ble først vurdert ut i fra tittel og sammendrag. Artikler på andre språk enn engelsk eller de skandinaviske ble ekskludert.

Søkene ga stor overlapping. Av 131 artikler gjennomgått i fulltekst ble 38 funnet relevante $\mathrm{i}$ henhold til inklusjons- og eksklusjonskriteriene (ramme 1). Vi inkluderte også 12 artikler fra referanselister og eget litteraturarkiv. Disse omhandlet primært beskrivelse av sykdomsmekanismer og behandling. Et oppdatert søk ble gjort for søket ble ytterligere tre artikler inkludert.

\section{Patogenese}

Kongenital trombotisk trombocytopenisk purpura (OMIM\# 274150) nedarves autosomalt recessivt og skyldes mutasjoner i ADAMTS13-genet (OMIM* 604134) på kromosom 9q34 $(4,7)$. Dette fører til en alvorlig mangel på enzymet ADAMTS13, perioden 16.3. 2015-16.3. 2016. Fra dette

\author{
Anne Sophie von Krogh \\ anne-sophie.v.krogh@ntnu.no \\ Institutt for kreftforskning og molekylær medisin \\ Norges teknisk-naturvitenskapelige universitet \\ Trondheim \\ og \\ Avdeling for blodsykdommer \\ St. Olavs hospital \\ Anders Waage \\ Institutt for kreftforskning og molekylær medisin \\ Norges teknisk-naturvitenskapelige universitet \\ Trondheim \\ og \\ Avdeling for blodsykdommer \\ St. Olavs hospital
}

\section{Petter Quist-Paulsen}

Institutt for kreftforskning og molekylær medisin Norges teknisk-naturvitenskapelige universitet Trondheim

og

Avdeling for blodsykdommer

St. Olavs hospital

> Se lederartikkel på side 1421

ID

Engelsk oversettelse på www.tidsskriftet.no

\section{HOVEDBUDSKAP}

Kongenital trombotisk trombocytopenisk purpura er en sjelden, arvelig tilstand som gir trombose, økt blødningstendens og anemi.

Tilstanden kan debutere først i voksen alder, ofte i forbindelse med graviditet

Kongenital trombotisk trombocytopenisk purpura er hyppigere i Norge enn ellers i verden, uten at vi sikkert vet hvorfor 


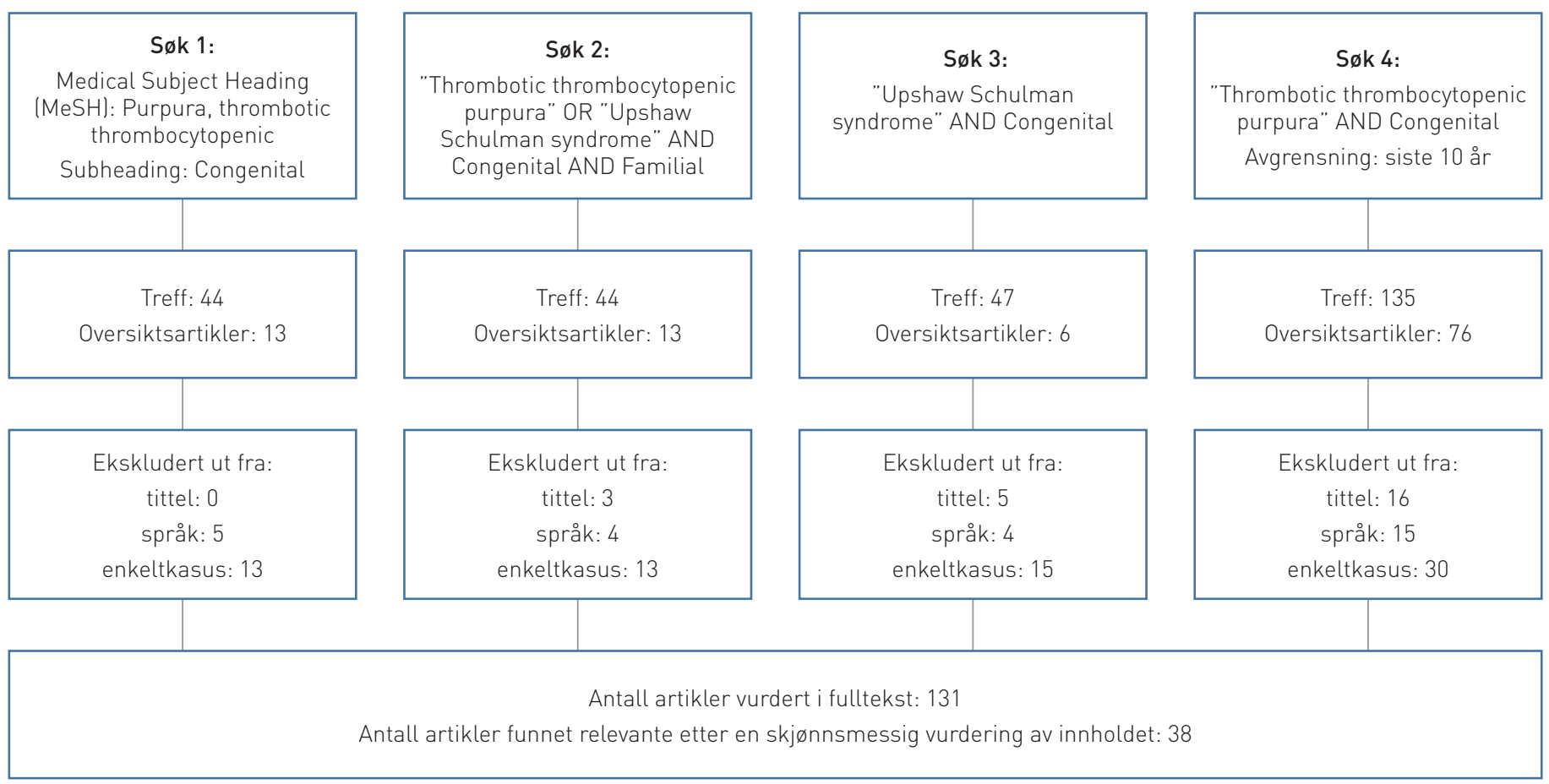

Figur 1 Oppsummering av litteratursøkene med antall treff på hvert trinn. Kun for søk 4 ble det gjort en tidsmessig avgrensning. Inklusjons- og eksklusjonskriterier er angitt i ramme 1. I trinn 1 ble de fleste artiklene ekskludert fordi de omhandlet enkelttilfeller eller enkeltmutasjoner uten relevans for den norske populasjonen. I trinn 2 ble de fleste artiklene ekskludert fordi de primært omhandlet ervervet trombotisk trombocytopenisk purpura eller fordi de ikke inneholdt nye pasientdata

enten via redusert syntese og sekresjon eller redusert spesifikk aktivitet.

ADAMTS13 spiller en viktig rolle i hemostasen ved å regulere størrelsen på von Willebrands faktor-multimerer $(8,9)$. Ved fravær av ADAMTS13 vil ultralange multimerer av von Willebrands faktor nå sirkulasjonen og stimulere plateadhesjon og -aggregasjon. Dermed kan det oppstå spontane tromber i mikrosirkulasjonen. Disse fører til forbruk av blodplater og iskemi i affiserte organer, som nyre, hjerne, hjerte og tarm.

ADAMTS13 syntetiseres i hovedsak i lever og karendotel, mens von Willebrands faktor produseres i endotelceller og megakaryocytter og lagres i Weibel-Palade-legemer i endotel og i alfakorn i blodplater (10). Først etter endotelaktivering når ultralange multimerer av von Willebrands faktor sirkulasjonen. Derfor må det til en stimulus som aktiverer endotel og frigjør von Willebrands faktor (f.eks. traume, infeksjon, svangerskap eller alkohol) før et anfall av trombotisk trombocytopenisk purpura (11).

\section{Andre årsaker til trombotisk trombocytopenisk purpura}

ADAMTS13-mangel kan oppstå som følge av autoantistoffer som hemmer ADAMTS13enzymet. Trombotisk trombocytopenisk purpura kan også forekomme uten ADAMTS13mangel - sekundært til utbredt kreftsykdom, hivinfeksjon, medikamentbruk eller etter allogen stamcelletransplantasjon (12).
I denne artikkelen har vi konsentrert oss om den arvelige varianten.

\section{Forekomst}

Insidensen av trombotisk trombocytopenisk purpura (uansett årsak) er på verdensbasis mellom 1,5 og 4 per million per år $(13,14)$. Over $90 \%$ av disse har ervervet trombotisk trombocytopenisk purpura. Prevalensen av den kongenitale formen er anslått til 1 per million $(15,16)$. Over 150 ulike mutasjoner i ADAMTS13-genet er beskrevet i relasjon til kongenital trombotisk trombocytopenisk purpura. De fleste er beskrevet i enkeltfamilier, men to mutasjoner med sannsynlig europeisk opphav er beskrevet i ulike familier fra Nord- og Sentral-Europa, USA, Canada og Australia (7, 17, 18).

I Norge kjenner vi til 19 familier med sykdommen. I helseregion Midt-Norge er det gjennomført en prevalensundersøkelse, der man fant en forekomst på 16,7 per million (19). Det er 15 ganger høyere enn det som er beskrevet i internasjonal litteratur, og den kongenitale formen var her hyppigere enn den ervervede.

Den høye forekomsten var relatert til ADAMTS13-mutasjonen

NM_139025.4(ADAMTS13): c.4143dupA (p.Glu1382Argfs), heretter omtalt som c.4143dupA. Av 18 pasienter med undersøkt ADAMTS13-genotype var 11 homozygote og tre sammensatt heterozygote for mutasjon c.4143dupA. Pasientene med denne mutasjonen bærer samme haplotype, og man antar derfor at en grunnleggereffekt av mutasjonen er forklaringen på den høye forekomsten $(17,19)$.

En grunnleggereffekt kan oppstå når en ny befolkning blir etablert av en liten gruppe av «grunnleggere» og dermed mister noe genetisk variasjon. Prevalensen av kongenital trombotisk trombocytopenisk purpura er

\section{RAMME 1}

\section{Inklusjonskriterier}

Kliniske studier der pasienter med kongenital trombotisk trombocytopenisk purpura er inkludert

Konsensusrapporter og terapianbefalinger Kasusserier og oversiktsartikler som inneholder fenotypedata

Enkeltkasuistikker med relevans for den norske pasientpopulasjonen

\section{Eksklusjonskriterier}

Rapporter som primært omhandler ervervet trombotisk trombocytopenisk purpura

Rapporter om enkeltmutasjoner som ikke er beskrevet i den norske populasjonen

Dobbeltpubliseringer (tidligere publiserte kasus i ny sammenheng uten nye data) 
ikke systematisk undersøkt for resten av Norge, men ligger sannsynligvis nærmere det man finner i resten av verden.

\section{Klinisk presentasjon i ulike livsfaser \\ Nyfødtperiode}

Forlenget icterus i nyfødtperioden kan være første tegn på kongenital trombotisk trombocytopenisk purpura. Av dem som senere fikk diagnosen, hadde $40-45 \%$ i nyfødtperioden forlenget icterus behandlet med utskiftningstransfusjon $(7,20)$.

Det er rapportert om uforklarte dødsfall etter anemi i nyfødtperioden hos søsken av pasienter med kjent sykdom (20-23). I andre tilfeller kan den hemolytiske krisen være selvbegrensende, uten organmanifestasjon eller sekvele. Hos nyfødte med hemolyse og trombocytopeni uten at det foreligger en annen sikker forklaring (f.eks. rhesusuforlikelighet) bør derfor ADAMTS13-aktivitetsanalyse utføres (fig 1).

\section{Småbarnsperiode}

Hos småbarn kan sykdommen debutere som episoder med hemolyse og trombocytopeni etter infeksjoner eller traumer. Hvis et slikt utbrudd kommer etter en episode med gastroenteritt, er tilstanden vanskelig å skille fra for eksempel hemolytisk-uremisk syndrom. Kombinasjonen hemolytisk anemi og trombocytopeni ses også ved Evans' syndrom, og mange barn med trombotisk trombocytopenisk purpura har først (feilaktig) fått denne diagnosen (24). Evans' syndrom er en form for autoimmun hemolytisk anemi med samtidig eller etterfølgende immunbetinget trombocytopeni. Disse pasientene har derfor, til forskjell fra pasienter med trombotisk trombocytopenisk purpura, en positiv direkte antiglobulintest.

Hos pasienter med kongenital trombotisk trombocytopenisk purpura er det sett en overhyppighet av nevropsykologiske utviklingsforstyrrelser. Vi vet ikke om dette skyldes anfall med påvirkning på sentralnervesystemet i nyfødtperioden, eller gjentatte mindre slike anfall senere.

\section{Svangerskap}

Nest etter nyfødtperioden er svangerskap det hyppigste tidspunkt for manifestasjon av tilstanden. Noen pasienter har vært asymptomatiske i nyfødtperioden og i barne- og ungdomsårene og får sitt første anfall under graviditet. Kvinner med kjent kongenital trombotisk trombocytopenisk purpura får alltid manifestasjon i svangerskapet dersom ikke nøye svangerskapsovervåking og forebyggende tiltak settes inn (25-27).

Svangerskap er en kraftig stimulus til endotelaktivering og frigjøring av von Willebrands faktor, og denne øker normalt $\mathrm{i}$ sirkulasjonen mot slutten av svangerskapet (2. og 3. trimester og post partum). Anfall av trombotisk trombocytopenisk purpura kommer typisk i denne perioden. Det gjør det vanskelig å skille disse fra andre, langt vanligere svangerskapskomplikasjoner som også forekommer i denne perioden, slik som preeklampsi og HELLP-syndrom ( $\mathrm{H}=$ hemolysis, EL = Elevated Liver enzymes, $\mathrm{LP}=$ Low Platelets).

\section{Ungdomstid og voksen alder}

Når barndommen er forbi, opplever mange pasienter at anfallsfrekvensen av trombotisk trombocytopenisk purpura går ned. Noen fortsetter å ha anfall relatert til tydelige utløsende faktorer - for eksempel alkoholinntak - inntil sammenhengen identifiseres og den utløsende årsaken elimineres. Andre utvikler en form for remitterende sykdom uten sikre utløsende faktorer eller en tilstand av vedvarende sykdomsaktivitet med tegn til hemolyse og trombocytopeni i laboratorieprøver. Utvikling av senkomplikasjoner som hypertensjon og progredierende nyresvikt kan komme i denne perioden.

Vi kjenner per i dag ikke til hvorfor pasienter med samme ADAMTS13-mutasjoner og i samme familie kan utvikle så ulike alvorlighetsgrader av sykdommen (28). Det er mulig at ulik eksponering for anfallsutløsende faktorer, annen samtidig morbiditet, polymorfismer i ADAMTS13-genet eller mutasjoner i andre gener kan spille en rolle (29).

\section{Diagnostikk}

Trombotisk trombocytopenisk purpura er en «øyeblikkelig hjelp»-diagnose som krever våkenhet hos klinikeren og igangsetting av behandling på mistanke, ofte før etiologisk diagnose er identifisert (fig 2). Diagnosen må mistenkes ved kombinasjonen trombocytopeni og mikroangiopatisk hemolytisk anemi. Mikroangiopati bekreftes ved funn av fragmenterte erytrocytter (schistocytter og hjelmceller) i blodutstryk. Mer enn $1 \%$ schistocytter uten andre vesentlige avvik $\mathrm{i}$ erytrocyttenes morfologi er av betydning.

Biokjemiske tegn på aktivert koagulasjon (forhøyet aktivert partiell tromboplastintid, protrombintid, D-dimer) ser man sjelden ved trombotisk trombocytopenisk purpura, til forskjell fra disseminert intravaskulær koagulasjon. Blodprøver til påvisning av ADAMTS13-mangel bør sikres før behandling med plasmaholdige blodprodukter. ADAMTS13-antigenmengde eller -aktivitet kan måles i citratplasma ved ELISA-basert eller FRET-basert metode (30-32). ADAMTS13-aktivitetsanalyse er etablert som et klinisk tilbud ved St. Olavs hospital fra oktober 2015. Der tar man imot prøver fra alle sykehuslaboratorier i Norge.

Alvorlig ADAMTS13-mangel er definert som $<10 \%$ av normal aktivitet. Prøven undersøkes da for tilstedeværelse av antistoff mot ADAMTS13. Ved fravær av disse mistenkes kongenital trombotisk trombocytopenisk purpura dersom sykehistorien ellers taler for det, mens diagnosen bekreftes ved funn av homozygot eller sammensatt heterozygot mutasjon etter sekvensering av ADAMTS13. Dersom pasientens blodtype er kjent, kan den molekylærgenetiske diagnostikken gjøres mer målrettet. Spesielt gjelder det mutasjon c.4143dupA, som er assosiert med blodtype B (19).

ADAMTS13-antistoffundersøkelse og molekylærgenetisk undersøkelse er så langt ikke tilgjengelig i Norge, men utføres ved Inselspital i Bern, Sveits.

\section{Behandling}

Akutte anfall hos pasienter med kongenital trombotisk trombocytopenisk purpura behandles med plasmaoverføring for å erstatte manglende ADAMTS13. Både ferskfryst plasma, solvent-detergent (SD)-plasma og faktor VIIIkonsentrat med intermediær renhetsgrad inneholder ADAMTS13 (33-35). I Norge brukes i praksis Octaplas (Octapharma, Wien), i døgndose $20-40 \mathrm{ml} / \mathrm{kg}$ kroppsvekt, ved akutte anfall.

Plasmautskiftning, som brukes ved antistoffmediert sykdom, er mer ressurskrevende enn plasmainfusjon og ikke nødvendig ved kongenital trombotisk trombocytopenisk purpura. Støttebehandling for affiserte organer gis etter behov, slik som dialyse ved akutt anurisk nyresvikt. Behandlingsvarighet med plasmainfusjon styres av klinisk effekt, der stigning i blodplatetall ofte er den beste indikatoren på behandlingsrespons (5).

Pasientene (eller deres foreldre) må lære seg å kjenne igjen symptomer på anfall, og ved annen akutt sykdom bør blodplatetallet alltid måles. Pasienter med gjentatte anfall, utvikling av permanent organskade eller vedvarende subkliniske tegn på hemolyse og trombocytopeni bør vurderes for anfallsforebyggende behandling.

Behandlingen tolereres vanligvis godt, men er tidkrevende. De fleste oppnår stabilisering av sykdommen ved infusjon av $10-15 \mathrm{ml}$ Octaplas per kilo hver 2.-3.uke, men behandlingsintervall og volum må tilpasses den enkelte pasient $(36,37)$. Det finnes ikke gode data for hvem som bør tilbys forebyggende behandling, men større kasusserier har vist at omtrent halvparten av pasientene får plasmaprofylakse $(19,20,29)$. Hos pasienter som behandles med forebyggende plasmainfusjoner gjennom flere år har man vært bekymret for utvikling av hemmende alloantistoffer mot ADAMTS13, slik man har sett hos pasienter med hemofili behandlet med faktorkonsentrat. Dette har imidlertid hittil ikke vært påvist hos pasien- 
ter med kongenital trombotisk trombocytopenisk purpura.

Nye prinsipper for behandling av kongenital trombotisk trombocytopenisk purpura er under klinisk utprøvning. ARC1779 er en syntetisk fremstilt aptamer som binder seg til von Willebrands faktor på bindingssetet for blodplater og hindrer von Willebrands faktor-mediert blodplateaktivering og trombose (38). Aptamerer er oligonukleotider som binder seg med høy affinitet og spesifisitet til bindingsseter og kan blokkere protein-protein-interaksjoner. Disse har så langt kun vært prøvd i en fase 1-/fase 2-studie (38).

Rekombinant fremstilt ADAMTS13 (rADAMTS13) er nettopp startet i klinisk utprøvning $i$ en fase 1-studie (39). Medikamentet kan kanskje lette hverdagen til pasienter som $i$ dag er avhengige av regelmessig plasmainfusjon. Håpet er at enklere administrering og eventuelt egenbehandling kan bli fremtiden for pasienter med kongenital trombotisk trombocytopenisk purpura, slik man har oppnådd for mange pasienter med hemofili.

\section{Oppfølging og kontroll}

Etter at diagnosen er satt, må pasient og pårørende få opplæring for raskt å kunne kjenne igjen symptomer på anfall, og det trengs en lavterskelkontakt til sykehus for behandling med plasma ved symptomer. Tidlig diagnose er sannsynligvis det viktigste tiltaket for å forebygge utvikling av senskader.

Pasientene bør ha regelmessig oppfølging av pediater eller hematolog som vurderer behovet for profylaktiske plasmainfusjoner og mulige organkomplikasjoner etter anfall og som kontrollerer nyrefunksjonen, generell kardiovaskulær risiko og nevropsykologisk funksjon.

Svangerskap er en høyrisikosituasjon og krever oppfølging av hematolog og fødselslege fra graviditeten er erkjent.

\section{Diskusjon}

Kongenital trombotisk trombocytopenisk purpura er en sjelden, arvelig tilstand, men verdt å kjenne til for norske leger av flere grunner. For det første er det en modellsykdom som har gitt kunnskap om samspillet mellom von Willebrands faktor og ADAMTS13 i normal hemostaseregulering. For det andre er kongenital trombotisk trombocytopenisk purpura en aktuell differensialdiagnose i flere livsfaser og i ulike kliniske situasjoner, og mange pasienter har opplevd diagnostisk forsinkelse. For det tredje har vi i Norge en opphopning av tilstanden som skyldes en grunnleggereffekt av mutasjonen c.4143dupA i ADAMTS13.

Tradisjonelt har trombotisk trombocytopenisk purpura vært karakterisert ved en samling av fem symptomer og funn: feber,

Uforklart forlenget icterus med behov for utskiftningstransfusjon

Kombinert hemolytisk anemi og trombocytopeni (DAT-negativ)

Atypisk hemolytisk-uremisk syndrom

Atypisk presentasjon av idiopatisk trombocytopenisk purpura

Trombocytopeni og nevrologiske symptomer

Residiverende trombocytopeni i forbindelse med infeksjoner

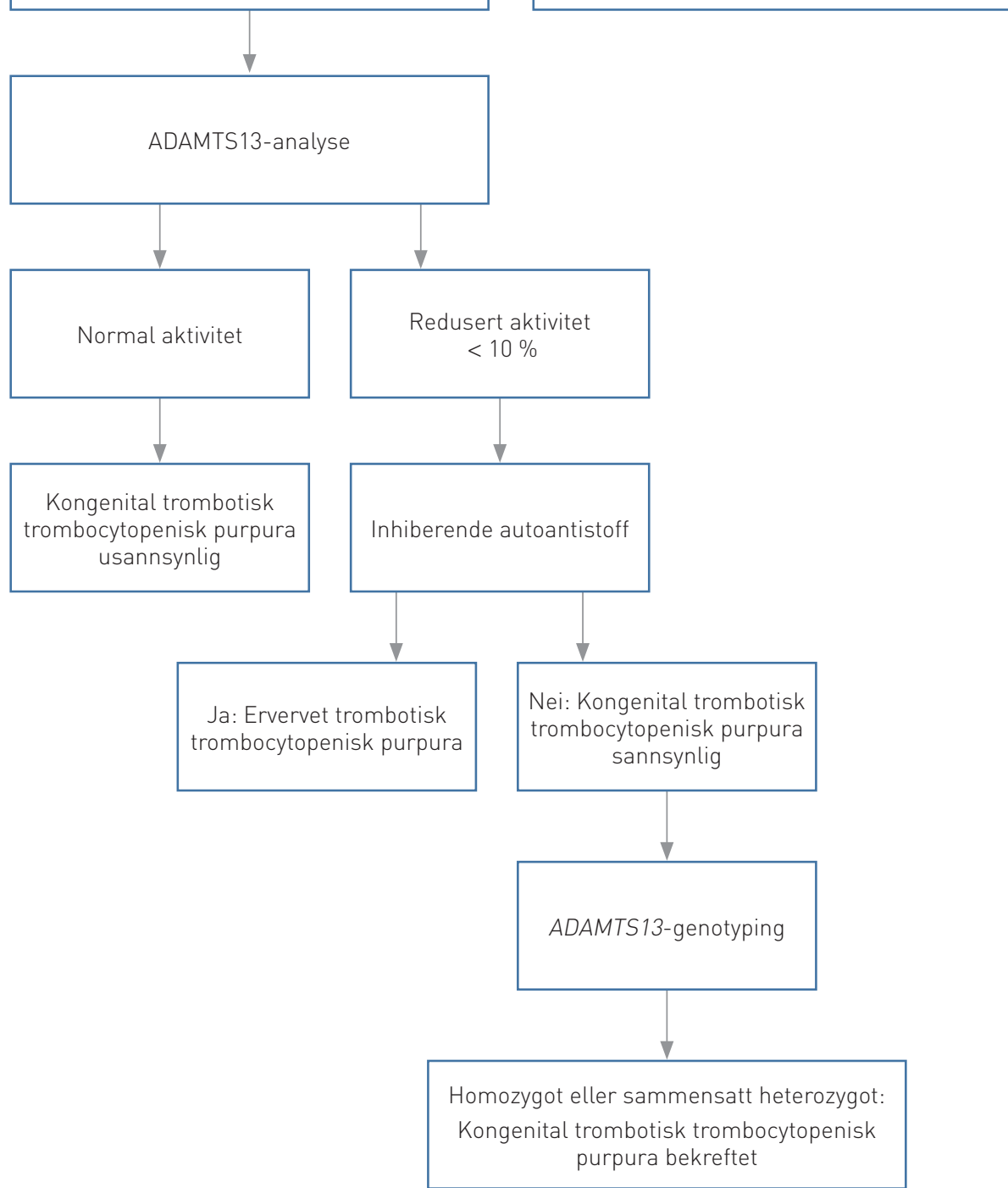

Figur 2 Tilstander som bør lede til utredning med tanke på kongenital trombotisk trombocytopenisk purpura, med algoritme for utredningen. Til høyre er det angitt typiske laboratoriefunn hos en pasient med kongenital trombotisk trombocytopenisk purpura

nyrepåvirkning, nevrologiske symptomer, mikroangiopatisk hemolytisk anemi og trombocytopeni (40). Det er imidlertid bare ved et mindretall av anfallene at alle fem tegn er til stede samtidig.

Oppmerksomhet, spesielt overfor nyfødte med forlenget icterus og gravide med trombocytopeni og hemolyse, kan være nøkkelen
Forventede laboratoriefunn hos en pasient med mistenkt trombotisk trombocytopenisk purpura:

- Hemoglobin: nedsatt, ev. normal initialt

- Trombocytter: sterkt nedsatt

- Laktatdehydrogenase: forhøyet

- Blodutstryk: schistocytter

- Direkte antiglobulintest: negativ

- Koagulasjonstester: normale til tidlig diagnose. ADAMTS13-analyse er nå lett tilgjengelig og kan i løpet av 2-4 uker bekrefte eller avkrefte diagnosen. Pasientens søsken bør tilbys genetisk veiledning. Fordi sykdommen har ulik ekspresjon (den kliniske presentasjonen kan variere) vil asymptomatiske søsken kunne ha alvorlig nedsatt ADAMTS13-aktivitet og få anfall 
dersom han eller hun utsettes for en tilstrekkelig stimulus, for eksempel infeksjon eller graviditet.

Vår litteraturgjennomgang har vist at der fortsatt finnes lite forskning om kongenital trombotisk trombocytopenisk purpura. Publiserte terapianbefalinger er basert på erfaring fra regionale eller nasjonale registre eller større sentre der disse pasientene behandles. For svært sjeldne sykdommer kan kasusserier og enkeltkasuistikker likevel være en viktig informasjonskilde.

Det gjenstår flere uavklarte spørsmål: ADAMTS13-mangel alene er ikke nok til å utløse anfall. Predileksjonssted for organskade varierer fra pasient til pasient. Hvorfor fenotypen varierer i så stor grad, til og med innen samme familie, reiser spørsmål om hvorvidt andre sykdomsmodifiserende gener eller miljøfaktorer spiller en rolle. Forebyggende plasmabehandling er antagelig nyttig, men vi vet lite om langtidseffektene, heller ikke om de som i dag ikke får profylaktisk behandling, burde ha hatt det. Kardiovaskulære dødsfall som skyldes storkarsykdom er beskrevet, men det er uavklart om pasientene har en overdødelighet som ikke er direkte relatert til anfall av trombotisk trombocytopenisk purpura.

For sjeldne sykdommer kan registerstudier være nyttige for å lære mer om det naturlige forløpet. Det finnes et internasjonalt pasientregister for kongenital trombotisk trombocytopenisk purpura der også norske pasienter deltar $(41,42)$. Innhenting av systematiske data er nødvendig for å utvikle behandlingsretningslinjer og for å få et bedre grunnlag for kunnskapsbasert praksis.

\section{Konklusjon}

Kongenital trombotisk trombocytopenisk purpura er en sjelden, arvelig sykdom med en uvanlig høy forekomst i Norge. Diagnosen stilles ved påvisning av alvorlig nedsatt ADAMTS13-aktivitet og homozygoti eller sammensatt heterozygoti for mutasjoner $\mathrm{i}$ ADAMTS13-genet.

Akutte anfall behandles med plasmainfusjon. Beslutningen om forebyggende plasmabehandling må individualiseres. Et kompetansesentertilbud for pasienter med kongenital trombotisk trombocytopenisk purpura, tilsvarende det pasienter med hemofili har, bør etableres.

Vi takker Jens Hammerstrøm og Lars Fredrik Engebretsen for konstruktive innspill i forbindelse med arbeidet med artikkelen.

\section{Anne Sophie von Krogh (f. 1974)}

er spesialist i indremedisin og lege i spesialisering i blodsykdommer.

Forfatter har fylt ut ICMJE-skjemaet og oppgir ingen interessekonflikter.

\section{Anders Waage (f. 1948)}

er spesialist i indremedisin og blodsykdommer. professor i blodsykdommer og avdelingsoverlege.

Forfatter har fylt ut ICMJE-skjemaet og oppgir ingen interessekonflikter.

\section{Petter Quist-Paulsen (f. 1969)}

er spesialist i indremedisin og i blodsykdommer, universitetslektor I og overlege.

Forfatter har fylt ut ICMJE-skjemaet og oppgir ingen interessekonflikter.

\section{Litteratur}

1. Schulman I, Pierce M, Lukens A et al. Studies on thrombopoiesis. I. A factor in normal human plasma required for platelet production; chronic thrombocytopenia due to its deficiency. Blood 1960; 16: 943-57.

2. Upshaw JD jr. Congenital deficiency of a factor in normal plasma that reverses microangiopathic hemolysis and thrombocytopenia. N Engl J Med 1978; 298: 1350-2.

3. Furlan M, Robles R, Solenthaler M et al. Deficient activity of von Willebrand factor-cleaving protease in chronic relapsing thrombotic thrombocytopenic purpura. Blood 1997; 89: 3097-103.

4. Levy GG, Nichols WC, Lian EC et al. Mutations in a member of the ADAMTS gene family cause throm botic thrombocytopenic purpura. Nature 2001 413: 488-94.

5. Loirat C, Girma JP, Desconclois C et al. Thrombotic thrombocytopenic purpura related to severe ADAMTS13 deficiency in children. Pediatr Nephrol 2009; 24: 19-29.

6. Gulati S, Siebke E, Gamlem AM. Et barn med resi diverende hemolytisk anemi og trombocytopeni. Tidsskr Nor Lægeforen 2007: 127: 884-5.

7. Lotta LA, Garagiola I, Palla R et al. ADAMTS13 mutations and polymorphisms in congenital thrombotic thrombocytopenic purpura. Hum Mutat 2010; 31: 11-9.

8. Furlan M, Robles R, Lämmle B. Partial purification and characterization of a protease from human plasma cleaving von Willebrand factor to fragments produced by in vivo proteolysis. Blood 1996 87: 4223-34.

9. Tsai HM. Physiologic cleavage of von Willebrand factor by a plasma protease is dependent on its conformation and requires calcium ion. Blood 1996; 87: 4235-44.

10. Crawley JT, de Groot R, Xiang Y et al. Unraveling the scissile bond: how ADAMTS13 recognizes and cleaves von Willebrand factor. Blood 2011; 118: 3212-21.

11. Furlan M, Lämmle B. Aetiology and pathogenesis of thrombotic thrombocytopenic purpura and haemolytic uraemic syndrome: the role of von Willebrand factor-cleaving protease. Best Pract Res Clin Haematol 2001; 14: 437-54.

12. Moake J. Thrombotic thrombocytopenia purpura (TTP) and other thrombotic microangiopathies. Best Pract Res Clin Haematol 2009; 22: 567-76.

13. Terrell DR, Williams LA, Vesely SK et al. The incidence of thrombotic thrombocytopenic purpurahemolytic uremic syndrome: all patients, idiopathic patients, and patients with severe ADAMTS- 13 deficiency. J Thromb Haemost 2005; 3: 1432-6.

14. Reese JA, Muthurajah DS, Kremer Hovinga JA et al. Children and adults with thrombotic thrombocytopenic purpura associated with severe, acquired Adamts 13 deficiency: comparison of incidence demographic and clinical features. Pediatr Blood Cancer 2013; 60: 1676-82.

15. Scully M, Yarranton H, Liesner R et al. Regional UK TTP registry: correlation with laboratory ADAMTS 13 analysis and clinical features. Br J Haematol 2008; 142: 819-26.

16. Kokame K, Kokubo Y, Miyata T. Polymorphisms and mutations of ADAMTS13 in the Japanese population and estimation of the number of patients with Upshaw-Schulman syndrome. J Thromb Haemost 2011; 9: 1654-6.

17. Schneppenheim R, Kremer Hovinga JA, Becker T et al. A common origin of the 4143insA ADAMTS13 mutation. Thromb Haemost 2006: 96: 3-6.

18. Camilleri RS, Cohen H, Mackie IJ et al. Prevalence of the ADAMTS-13 missense mutation R1060W in late onset adult thrombotic thrombocytopenic purpura. J Thromb Haemost 2008; 6: 331-8.

19. von Krogh AS, Quist-Paulsen P. Waage A et al. High prevalence of hereditary thrombotic thrombocytopenic purpura in central Norway: from clinical observation to evidence. J Thromb Haemost 2016: 14: 73-82.

20. Fujimura Y, Matsumoto M, Isonishi A et al. Natural history of Upshaw-Schulman syndrome based on ADAMTS13 gene analysis in Japan. J Thromb Haemost 2011:9 (suppl 1): 283-301.

21. Barbot J, Costa E, Guerra M et al. Ten years of prophylactic treatment with fresh-frozen plasma in a child with chronic relapsing thrombotic thrombocytopenic purpura as a result of a congenital deficiency of von Willebrand factor-cleaving protease. Br J Haematol 2001: 113: 649-51.

22. Mansouri Taleghani M, von Krogh AS, Fujimura Y et al. Hereditary thrombotic thrombocytopenic purpura and the hereditary TTP registry. Hamostaseologie 2013; 33: 138-43.

23. Loirat C, Veyradier A, Girma JP et al. Thrombotic thrombocytopenic purpura associated with von Willebrand factor-cleaving protease (ADAMTS13) deficiency in children. Semin Thromb Hemost 2006: 32: 90-7.

24. Schneppenheim R, Budde U, Hassenpflug W et al. Severe ADAMTS-13 deficiency in childhood. Semin Hematol 2004; 41: 83-9.

25. Fujimura Y, Matsumoto M, Kokame K et al. Pregnancy-induced thrombocytopenia and TTP and the risk of fetal death, in Upshaw-Schulman syndrome: a series of 15 pregnancies in 9 genotyped patients. Br J Haematol 2009; 144: 742-54.

26. Scully M, Thomas M, Underwood M et al. Thrombotic thrombocytopenic purpura and pregnancy: presentation, management, and subsequent pregnancy outcomes. Blood 2014; 124: $211-9$

27. von Krogh AS, Kremer Hovinga JA, Tiønnfjord GE et al. The impact of congenital thrombotic throm bocytopenic purpura on pregnancy complications. Thromb Haemost 2014; 111: 1180-3.

28. Hassenpflug WA, Budde U, Schneppenheim S et al. Inherited thrombotic thrombocytopenic purpura in children. Semin Thromb Hemost 2014: 40: 487-92.

29. Lotta LA, Wu HM, Mackie IJ et al. Residual plasmatic activity of ADAMTS13 is correlated with phenotype severity in congenital thrombotic thrombocytopenic purpura. Blood 2012; 120: $440-8$

30. Kremer Hovinga JA, Mottini M, Lämmle B. Measurement of ADAMTS-13 activity in plasma by the FRETS-VWF73 assay: comparison with other assay methods. J Thromb Haemost 2006: 4: 1146-8.

31. Peyvandi F, Palla R, Lotta LA et al. ADAMTS-13 assays in thrombotic thrombocytopenic purpura. J Thromb Haemost 2010; 8: 631-40.

32. Mackie I, Langley K, Chitolie A et al. Discrepancies between ADAMTS13 activity assays in patients with thrombotic microangiopathies. Thromb Haemost 2013; 109: 488-96.

33. Scully M, Gattens M, Khair K et al. The use of intermediate purity factor VIII concentrate BPL $8 Y$ as prophylaxis and treatment in congenital thrombotic thrombocytopenic purpura. Br J Haematol 2006; 135: $101-4$

34. Scott EA, Puca KE, Pietz BC et al. Comparison and stability of ADAMTS13 activity in therapeutic plasma products. Transfusion 2007; 47: $120-5$.

35. Heger A, Kannicht C, Römisch J et al. Normal levels of ADAMTS13 and factor $\mathrm{H}$ are present in the pharmaceutically licensed plasma for transfusion (Octaplas) and in the universally applicable plasma (Uniplas) in development. Vox Sang 2007; 92: 206-12 
36. Scully M, Hunt BJ, Benjamin S et al. Guidelines on the diagnosis and management of thrombotic thrombocytopenic purpura and other thrombotic microangiopathies. Br J Haematol 2012; 158: $323-35$.

37. Knöbl PN. Treatment of thrombotic microangiopathy with a focus on new treatment options. Hamostaseologie 2013; 33: 149-59.

38. Jilma-Stohlawetz P, Gilbert JC, Gorczyca ME et al. A dose ranging phase I/II trial of the von Willebrand factor inhibiting aptamer ARC1779 in patients with congenital thrombotic thrombocytopenic purpura. Thromb Haemost 2011; 106: 539-47.

39. Phase 1 Dose Escalation, Single Dose Study to Assess Safety and Pharmacokinetics of BAX930 in Hereditary Thrombotic Thrombocytopenic Purpura (TTP). NCT02216084. https://clinicaltrials.gov/ (1.7.2016)

40. Amorosi EL, Ultmann JE. Thrombotic thrombocytopenic purpura: report of 16 cases and review of the literature. Medicine (Baltimore) 1966; 45: 139-60.

41. Hereditary Thrombotic Thrombocytopenic Purpura - Upshaw-Schulman Syndrome. www.ttpregistry.net (1.7.2016).

42. Genotype and Phenotype Correlation in Hereditary Thrombotic Thrombocytopenic Purpura (UpshawSchulman Syndrome). (TTP registry).

NCT01257269. https://clinicaltrials.gov/ (1.7.2016).

Mottatt 7.12. 2015, første revisjon innsendt 6.5.

2016, godkjent 1.7. 2016. Redaktør: Ragnhild

Ørstavik. 